white aesthetic score assesses the parameters of tooth form, outline, colour, texture and translucency (Belser et al.). ${ }^{33}$ Although this provides a quantifiable outcome score, it does not quantify the severity of a discrepancy as a continuous dataset and does not relate the significance of each factor to the aesthetic concern of patients.

The use of digital scanning would allow for superimposition and mirroring to assess the outcomes and give continuous data scores or values to reflect the absolute symmetry. Current scanners can also assess tissue colour and surface texture. These scores could be correlated to visual subjective assessments and perhaps a threshold identified in a similar vein to that of intraoral colour discrepancies where a critical $\Delta \mathrm{E}$ value of 3.7 has been identified. ${ }^{34}$

Further research also needs to be conducted to compare the various scanning techniques in use to assess their reproducibility and accuracy to one another. Each has been tested individually, but to the authors' knowledge, there has been no direct comparison in this field.

\section{Conclusion}

Intraoral scanning technologies present an opportunity to assess and monitor soft tissue changes in a dimension not previously recorded. They have proven accurate enough to generate meaningful and novel data, although further work needs to be carried out in order to address technical complexities, such as scanning mobile tissues. The insight these technologies provide when measuring volumetric data may have a profound impact on our understanding of the requirements for successful soft tissue augmentation procedures and generate datasets that help better inform patients as to the expected outcomes of such procedures.

\section{References}

1. Patzelt S B M, Lamprinos C, Stampf S, Att W. The time efficiency of intraoral scanners: an in vitro comparative study. J Am Dent Assoc 2014; 145: 542-555.
2. Christensen G J. Will digital impressions eliminate the current problems with conventional impressions? J Am DentAssoc 2008; 139: 761-763.

3. Richert R, Goujat A, Venet L et al. Intraoral Scanner Technologies: A review to Make a Successful Impression. J Health Eng 2017; DOI: 10.1155/2017/8427595

4. Martin C B, Chalmers EV, Mclntyre G T, Cochrane H, Mossey P A. Orthodontic scanners: what's available? J Orthod 2015: 42: 136-143.

5. Ender A, Attin T, Mehl A. In vivo precision of conventional and digital methods of obtaining complete-arch dental impressions. J Prosthet Dent 2016: 115: $313-320$.

6. Vasudavan S, Sullivan SR, Sonis A L. Comparison of intraoral 3D scanning and conventional impressions for fabrication of orthodontic retainers. J Clin Orthod 2010; 44: 495-497.

7. Lanis A, Álvarez Del Canto O. The combination of digital surface scanners and cone beam computed tomography technology for guided implant surgery using 3Shape implant studio software: a case history report. Int I Prosthodont 2015: 28: 169-178.

8. Mangano F, Gandolfi A, Luongo G, Logozzo S. Intraoral scanners in dentistry: a review of the current literature. BMC Oral Health 2017; 17: 149

9. Zimmermann M, Mehl A, Mörmann W H, Reich S. Intraoral scanning systems - a current overview. Int J Comput Dent 2015; 18: 101-129.

10. Kim J, Park J M, Kim M, Heo S J, Shin I H, Kim M. Comparison of experience curves between two 3dimensional intraoral scanners. J Prosthet Dent 2016; 116: $221-230$

11. Imburgia M, Logozzo S, Hauschild U, Veronesi $\mathrm{G}$, Mangano C, Mangano F G. Accuracy of four intraoral scanners in oral implantology: a comparative in vitro study. BMC Oral Health 2017: 17: 92

12. Jemt T. Regeneration of gingival papillae after singleimplant treatment. Int J Periodontics Restorative Dent 1997: 17: 326-333.

13. Nordland W P, Tarnow DP. A classification system for loss of papillary height. J Periodontol 1998; 69: 1124-1126.

14. Cardaropoli D, Re S, Corrente G. The Papilla Presence Index (PPI): a new system to assess interproximal papillary levels. Int J Periodontics Restorative Dent 2004; 24: 488-492.

15. Miller Jr P D. A classification of marginal tissue recession. Int J Periodontics Restorative Dent 1985; 5: 8-13.

16. Rotundo R, Mori M, Bonaccini D, Baldi C. Intraand inter-rater agreement of a new classification system of gingival recession defects. Eur J Oral Implantol 2011; 4: 127-133.

17. Lindström $M J R$, Ahmad $M$, Jimbo $R$, Ameri $A$, Von Steyern PV, Becktor J P. Volumetric measurement of dentoalveolar defects by means of intraoral 3D scanne and gravimetric model. Odontology 2019; 107: 353.

18. Studer S P, Sourlier D, Wegmann U, Schärer P, Rees T D. Quantitative measurement of volume changes induced by oral plastic surgery: validation of an optical method using different geometrically-formed specimens. J Periodontol 1997; 68: 950-962

19. Windisch S I, Jung R E, Sailer I, Studer S P, Ender A, Hammerle C H. A new optical method to evaluate threedimensional volume changes of alveolar contours: a methodological in vitro study. Clin Oral Implants Res 2007: 18: 545-551.
20. Fickl S, Schneider D, Zuhr 0 et al. Dimensional changes of the ridge contour after socket preservation and buccal overbuilding: an animal study. J Clin Periodontol 2009; 36: 442-448

21. Thoma D S, Jung R E, Schneider D et al. Soft tissue volume augmentation by the use of collagenbased matrices: a volumetric analysis. J Clin Periodontol 2010; 37: 659-666.

22. Strebel J, Ender A, Paqué $F$, Krähenmann $M$, Attin $T$, Schmidlin P R. In vivo validation of a three-dimensional optical method to document volumetric soft tissue changes of the interdental papilla. J Periodontol 2009; 80: 56-61.

23. Schneider D, Grunder U, Ender A, Hammerle C H F Jung R E. Volume gain and stability of peri-implant tissue following bone and soft tissue augmentation: 1 year results from a prospective cohort study. Clin Oral Implants Res 2011; 22: 28-37.

24. Sanz Martin I, Benic G I, Hammerle C H, Thoma D S. Prospective randomized controlled clinical study comparing two dental implant types: volumetric soft tissue changes at 1 year of loading. Clin Oral Implants Res 2015; 27: 406-411.

25. Bienz S P, Sailer I, Sanz-Martin I, Jung R E, Hammerle C H F, Thoma D S. Volumetric changes at pontic sites with or without soft tissue grafting: a controlled clinical study with a 10-year follow-up. J Clin Periodontol 2017; 44: $178-184$

26. Lehmann K M, Kasaj A, Ross A, Kammerer P W, Wagner W, Scheller H. A new method of volumetric evaluation of gingival recession: A feasibility study. J Periodontol 2012; 83: 50-54.

27. Mehl A, Gloger W, Kunzelmann K H, Hickel R. A new optical 3D device for the detection of wear. J Dent Res 1997: 76: 1799-1807.

28. Schneider D, Ender A, Truninger T et al. Comparison between clinical and digital soft tissue measurements. J Esthet Restor Dent 2014: 26: 191-199.

29. Rebele S F, Zuhr O, Schneider D, Jung R E, Hürzeler M $B$. Tunnel technique with connective tissue graft versus coronally advanced flap with enamel matrix derivative for root coverage: a RCT using 3D digital measuring methods. Part II. Volumetric studies on healing dynamics and gingival dimensions. J Clin Periodontol 2014; 41: 593-603.

30. Bienz S P, Jung R E, Sapata V M, Hammerle C H F, Husler J, Thoma D S. Volumetric changes and peri-implant health at implant sites with or without soft tissue grafting in the esthetic zone, a retrospective casecontrol study with a 5year follow-up. Clin Oral Implants Res 2017; 28: 1459-1465.

31. Chen S Y, Liang W M , Chen F N. Factors affecting the accuracy of elastometric impression materials. J Dent 2004; 32: 603-609.

32. Zadeh $\mathrm{HH}$ Abdelhamid A, Omran M, Bakhshalian $\mathrm{N}$, Tarnow D. An open randomized controlled clinical trial to evaluate ridge preservation and repair using SocketKAP( $\left.{ }^{\mathrm{TM}}\right)$ and SocketKAGE $\left({ }^{\mathrm{T}}\right)$ : part 1threedimensional volumetric soft tissue analysis of study casts. Clin Oral Implants Res 2016; 27: 640-649

33. Belser U C, Grutter L, Vailati F, Bornstein M M, Weber HP, Buser D. Outcome evaluation of early placed maxillary anterior single-tooth implants using objective esthetic criteria: A cross-sectional, retrospective study in 45 patients with a 2 to 4 year follow up using pink and white esthetic scores.J Periodontol 2009; 80: 140-151.

34. Johnston W M, Kao E C. Assessment and Appearance Match by Visual Observation and Clinical Colorimetry. J Dent Res 1989; 68: 819-822.

\title{
Correction to: Dental core training: the trainee perspective
}

The original article can be found online at https://doi.org/10.1038/s41415-020-1534-6.

Author's correction note:

Education article Br Dent J 2020; 228: 782-790.

When initially published the wording on the y-axis of figures $4-15$ was ordered incorrectly.

The original article has been corrected. 